\title{
The number of CCR5 expressing CD4+ $T$ lymphocytes is lower in HIV-infected long-term non-progressors with viral control compared to normal progressors: a cross-sectional study
}

Hinta Meijerink', Agnes R Indrati², Reinout van Crevel ${ }^{1}$, Irma Joosten ${ }^{3}$, Hans Koenen ${ }^{3}$ and Andre JAM van der Ven ${ }^{*}$

\begin{abstract}
Background: The HIV co-receptors CXCR4 and CCR5 play an important role in HIV infection and replication. Therefore we hypothesize that long-term non-progressors (LTNP) with viral control have lower expression of CCR5 and CXCR4 on CD4 ${ }^{+}$cells, specifically on memory T-lymphocytes since they are the primary target cells of HIV.

Methods: In this cross-sectional study, we included five HIV-infected LTNP with viral control (CD4 $>750$ cell/ $/$ I \& $H I V<50$ copies for $\geq 2$ years), thirteen HIV-infected and seven HIV-uninfected individuals at Radboud UMC Nijmegen, the Netherlands. We determined the CCR5 and CXCR4 expression among CD4 ${ }^{+}$and CD8 $8^{+}$lymphocyte subsets; memory $\left(C D 45 \mathrm{RO}^{+}\right)$, naïve $\left(\mathrm{CD} 45 \mathrm{RA}^{+}\right)$cells and regulatory T-cells $\left(\mathrm{CD} 4^{+} \mathrm{CD} 25^{\text {high }} \mathrm{FoxP3}^{+}\right)$. In addition, CCR5 32 polymorphism is related with disease progression and was therefore determined using polymerase chain reaction.

Results: The percentage of CCR5-expressing CD4 ${ }^{+}$cells of LTNP was comparable with healthy controls; whereas HIV-infected individuals showed more CCR5-expressing cells. This was observed in memory and naïve CD4 ${ }^{+}$cells, but not in regulatory T-cells. The mean fluorescence intensity of CCR5-expressing CD4 ${ }^{+}$cells was similar in all groups. All groups had comparable percentages of CXCR4-expressing cells. The mean fluorescence intensity of CXCR4-expressing cells was significantly higher in HIV-infected normally progressors in both memory and naïve $\mathrm{CD}^{+}$cells, but not in $\mathrm{CD} 8^{+}$cells. The CCR5 32 polymorphism was not related to group.

Conclusions: We show that HIV affects -directly or indirectly- the expression of CCR5 in CD4 ${ }^{+}$T-lymphocytes; yet this effect is not seen in LTNP with viral control. Avoiding upregulation of CCR5 could be an important method via which LTNP counteracts the effects of HIV and suppresses viral replication. Exploring how LTNP suppress the upregulation of CCR5 could be an important step for discovering new therapeutics.
\end{abstract}

Keywords: HIV, CCR5, CXCR4, Elite controllers, T-lymphocytes, Regulatory T-cells, Memory T cells, Naïve T cells, HIV co-receptors

\footnotetext{
* Correspondence: Andre.vanderVen@radboudumc.nl

${ }^{1}$ Department of Internal Medicine, Radboud University Medical Center, Route 456, PO Box 910, 6500 HB, Nijmegen, The Netherlands

Full list of author information is available at the end of the article
} 


\section{Background}

Human immunodeficiency virus (HIV) infects and destroys $\mathrm{CD} 4^{+}$T-lymphocytes. Resting $\mathrm{CD} 4^{+} \mathrm{T}$-lymphocytes are a reservoir of HIV infection; subsets of these lymphocytes are differentially affected by HIV and subdividing these cells in memory and naïve cells can provide better understanding of their individual roles [1,2]. Memory T-lymphocytes are preferentially targeted by HIV, whereas increased numbers of regulatory T-cells are associated with disease progression [3]. The density of the CD4 surface marker is associated with both HIV RNA viral load and disease progression [4]. In addition to CD4 receptors HIV requires a co-receptor, either CCR5 or CXCR4, to invade cells. In general, HIV isolated from newly infected individuals uses CCR5 and these "R5 variants" are detectable over the entire course of the HIV infection [5]. The X4 variants, that utilize CXCR4, are mostly detectible at a late stage of the disease and in only up to $50 \%$ of all patients [6]. Both co-receptors are expressed on leukocytes, but to different extents on different T-cell subsets $[7,8]$. CXCR4 is predominantly found on resting, naive T-lymphocytes, whereas CCR5 is expressed on mostly memory T-lymphocytes. Therefore activated $\mathrm{CD} 4^{+} \mathrm{CCR} 5^{+}$T-lymphocytes are the primary target and an optimal subset for virus replication [2].

The number of circulating CD4 cells accurately reflects the extent of immunodeficiency in HIV-infected patients. Most HIV-infected patients exhibit a gradual decline in CD4 cells throughout the course of their infection; the rate of disease progression from asymptomatic HIV infection to AIDS varies between patients. Some HIV patients are able to maintain stable CD4 cell counts for an extended time and remain asymptomatic without ART for years after infection. These patients have been referred to as long-term non-progressors (LTNP). Unfortunately, the underlying mechanisms for the interindividual variability and slow progression of HIV are poorly understood. Understanding mechanisms that are associated with slow progression will help identify new targets for treatment and even prevention of HIV infection.

The HIV co-receptors CCR5 and CXCR4 could play a crucial role in the progression of HIV and non-progression among LTNP. A well-known polymorphism in the CCR5 gene, namely CCR5 $\Delta 32$ (a 32 base pair deletion in the CCR5 gene) interrupts the entrance of HIV into cells and individuals homozygous for this deletion are almost completely resistant to HIV infection [9-12]. And individuals who are heterozygous for the CCR $5 \Delta 32$ have shown slower progression of HIV [9,13-15]. Also the expression of CCR5 and CXCR4 is, in addition to CD4, extremely important in the susceptibility of cells to HIV infection [16] and viral replication $[17,18]$. Previous studies have shown that the expression of CCR5 increased with HIV disease progression, a phenomenon that is reversed by antiretroviral therapy (ART) [19]; indicating that CCR5 expression is important in disease progression. Not only the receptors, but also its ligands (MIP-1 $\alpha /$ CCL3, MIP- $1 \beta / C C L 4$ and RANTES/CCL5 for CCR5 and SDF-1/CXCL12 for CXCR4) have the ability to block HIV activity [12]. Unfortunately, only little information is available on the expression of CXCR4 and CCR5 on different subsets of T-lymphocytes, especially in relation to LTNP. Therefore, we have explored differences in the expression of CCR5 and CXCR4 in different subsets of T-lymphocytes in LTNP with viral control.

\section{Methods}

\section{Study population}

HIV seropositive, ART-naïve subjects above 18 years of age were included at the HIV-clinic of the Radboud University Nijmegen Medical Centre, the Netherlands. LTNP with viral control were defined as those with a CD4 cell count above 750 cells/ $\mu \mathrm{l}$ and a HIV viral load below 50 copies/ml for at least 2 years $[10,20]$. HIV-infected subjects that did not fit these criteria were classified as HIV-infected normal progressors, and HIV seronegative healthy individuals were used as controls. Blood samples of LTNP were always examined in parallel with samples from a healthy control donor and multiple HIV-infected normal progressors. Blood samples were used for standard hematologic blood parameters and flow cytometry.

\section{Ethics}

This study was presented to the institutional review board of Radboud UMC in Nijmegen, the Netherlands. We received a waiver for blood collection of HIV infected individuals and approval for blood collection of healthy controls from the Medical Ethical Committee Nijmegen in the Netherlands. All participants, including healthy controls, were informed about giving blood samples for this specific study and provided written consent. During a routine appointment, nurses in the clinic collected the blood samples and provided these to us anonymously. None of the researchers had access to participants personal identifying data and all data was analysed anonymously.

\section{Flow cytometry}

Cells were phenotypically analysed by five-colour flow cytometry (Coulter Cytomics FC 500, Beckman Coulter, Fullerton, CA) using Coulter Epics Expo 32 software. Both peripheral blood mononuclear cells (PBMC) and whole blood (after red cell lysis) were used for flow cytometric analysis. PBMC were isolated by density centrifugation on Ficoll-Hypaque (Pharmacia Biotech, Uppsala, Sweden). Red cell lysis of whole blood was performed according to the manufacturer's instruction (BD PharmLyse, Becton Dickinson Biosciences, San Jose, USA). Cells were washed with phosphate-buffered saline (PBS) with $1 \%$ bovine serum albumin (BSA) before being incubated with 
fluorochrome- conjugated mAbs. After incubation for $20 \mathrm{~min}$ at room temperature, cells were washed twice to remove unbound antibodies and analysed. For cell surface staining, the following mAbs were used: CD25-PECy7 (BC96), CD127 PECy5 and PECy7 labelled (RDR5) from eBioscience (San Diego, USA); CD3-ECD (UCHT1) and CD4-ECD (SFCI12T4D11) from Beckman Coulter (San Diego, USA); CD4-PECy7 (RPA-T4), CD8-PECy7 (HIT8a), CD45-APC (HI30), CD14-APC (M5E2), CD19PECy7 (HIB19), CD45RO-APC (UCHL1), CD45RA-APC (HI100), CXCR4-PE (12G5), CCR5-FITC (HEK/1/85a) from Biolegend (San Diego, USA). Appropriate isotype control mAbs were used for gate settings. Due to limited amount of filters per sample memory and naïve lymphocytes were identified using CD3 and CD4 in combination with CD45RO or CD45RA respectively. The live gate was set based on the forward angle light scatter (FSCs) and the side angle light scatter (SSCs). For intracellular staining for FoxP3 we used FoxP3-APC antibodies (PCP101; eBioscience). Before intracellular staining, cells were fixed and permeabilised using Fix and Perm reagent according to the manufacturer's recommendations (eBioscience).

\section{DNA isolation and polymerase chain reaction}

DNA was isolated from PBMCs by Puregene DNA isolation kits (Gentra Puregene blood kit, Qiagen, Hilden, Germany) according to manufacturer's instruction. Briefly, cells were lysed overnight at $37^{\circ} \mathrm{C}$ before adding protein precipitation solution. DNA was purified using isopropanol, washed with $70 \%$ ethanol, and then diluted in $10 \mu \mathrm{l}$ of DNA hydrolysation solution and incubated overnight at $37^{\circ} \mathrm{C}$. Hydrolysation solution without DNA was used as a negative control. DNA concentrations were measured using Nanodrop and samples were stored at $4^{\circ} \mathrm{C}$ until analysis. To determine the $32 \mathrm{bp}$ deletion in the CCR5 gene $(C C R 5 \Delta 32)$ we used polymerase chain reaction (PCR) with the following primers: forward primer 5'-ATCACTTGGGTGGTGGCTGTGTTTGCGTCTC-3' and reverse primer 3'-GACGGCGACGAACAGTACCA GTAGACGATGA-5', corresponding to bases 505-535 and 667-697 [21]. Genomic DNA from each individual was amplified in a total volume of $25 \mathrm{uL}$ in a buffer containing $10 \mu \mathrm{M}$ of each primer. The cycling conditions were: denaturation at $94^{\circ} \mathrm{C}$ for $5 \mathrm{~min}$ (1 cycle), followed $94^{\circ} \mathrm{C}$ for $60 \mathrm{sec}$ and $70^{\circ} \mathrm{C}$ for $30 \mathrm{sec}$ for 35 cycles. The CCR5 32 polymorphism was detected with electrophoresis with $4 \%$ agarose gel stained with ethidium bromide. The normal allele size is $193 \mathrm{bp}$ and the allele size for the deletion is $161 \mathrm{bp}$.

\section{Statistical analyses}

We selected subsets of cells by first gating on live cells and subsequently on CD45+ cells. Within these gated cells we defined the subsets as follows: monocytes: $\mathrm{CD} 14^{+}$; B-cells: CD19 ${ }^{+}$; T-lymphocytes: $\mathrm{CD}^{+}$. In the $\mathrm{CD}^{+}$cells we gated on either on $\mathrm{CD} 4^{+}$or $\mathrm{CD}^{+}$cells. Further, within these $\mathrm{CD} 4^{+}$or $\mathrm{CD}^{+}$cells we identified $\mathrm{CD} 45 \mathrm{RA}^{+}$(naïve), $\mathrm{CD}_{45 \mathrm{RO}^{+}}$(memory) and $\mathrm{CD} 25^{\text {high }} \mathrm{FoxP}^{+}$(regulatory). In Figure 1A we give an example of how memory cells were selected. First we selected all CD $45^{+}$cells and plotted CD3 and CD4 markers in a scatterplot (left), then we selected all $\mathrm{CD}_{4}^{+} \mathrm{CD}^{+}$cells and plotted $\mathrm{CD} 4$ and CD45RO markers in a second scatterplot (right). In this plot we identified memory cells as $\mathrm{CD} 45 \mathrm{RO}^{+} \mathrm{CD}^{+}$cells. In Figure $1 \mathrm{~B}$ we plotted $\mathrm{CD} 25$ and $\mathrm{CD} 4$ markers and identified regulatory $\mathrm{T}$ cells as being expressing CD25 high, CD4 and FoxP3. For all cell subtypes, expression of HIV co-receptors CCR5 and CXCR4 was measured as proportion (\%) of positive cells, as well as mean fluorescence intensity (MFI) of positive cells. The Kruskal Wallis and Mann Whitney analyses were used to compare differences between groups. The level of significance was set at $10 \%$. All statistical analysis was performed using the Statistical Product and Services Solutions package version 18.0 and GraphPad Prism version 5.0.

\section{Results}

We included five HIV-infected LTNP with viral control, thirteen HIV-infected normal progressors and seven healthy controls. None of the HIV-infected subjects took ART at time of blood collection or previously. The characteristics of the subjects are shown in Table 1; as expected the median CD4 cells were higher and the viral load was lower in HIV-infected LTNP than in normal progressors. HIV was diagnosed a median of eight years (range: 3-14 years) for LTNP and a median of three and a half years (range: 1-7 years) for other HIV infected individuals.

Differences in cell type distribution between groups were most pronounced for $\mathrm{CD} 4^{+}$subtypes (Table 2 ). As expected, HIV-infected normal progressors had significantly lower $\mathrm{CD}^{+}{ }^{+}$T-cell counts compared to LTNP and healthy controls (Table 2). This difference was found for all $\mathrm{CD}^{+}$subsets: memory $\left(\mathrm{CD} 45 \mathrm{RO}^{+}\right)$, naïve $\left(\mathrm{CD} 45 \mathrm{RA}^{+}\right)$ and regulatory $\left(\mathrm{CD} 25^{\text {high }} \mathrm{FoxP}^{+}\right.$cells) T-lymphocytes.

Expression of the HIV co-receptor CCR5 on CD4 ${ }^{+}$T-cells was similar in LTNP and healthy controls; both groups showed lower CCR5 expression compared to HIV-infected normal progressors (Figure 2A). When CD4-cell subsets were analysed, this difference was observed in memory and naïve T-lymphocytes ( $\mathrm{p}$-values: 0.007 and 0.046 respectively), but not in regulatory $\mathrm{T}$-cells $(\mathrm{p}=0.443)$ (Figure 2A). $\mathrm{CD}^{+} \mathrm{T}$-lymphocytes did not show a difference in CCR5 expression.

The MFI of CCR5-expressing cells in CD4 ${ }^{+}$T-lymphocytes was slightly higher in LTNP and HIV-infected individuals (Figure 2B; not significant). In all $\mathrm{CD}^{+} \mathrm{T}$-lymphocyte 


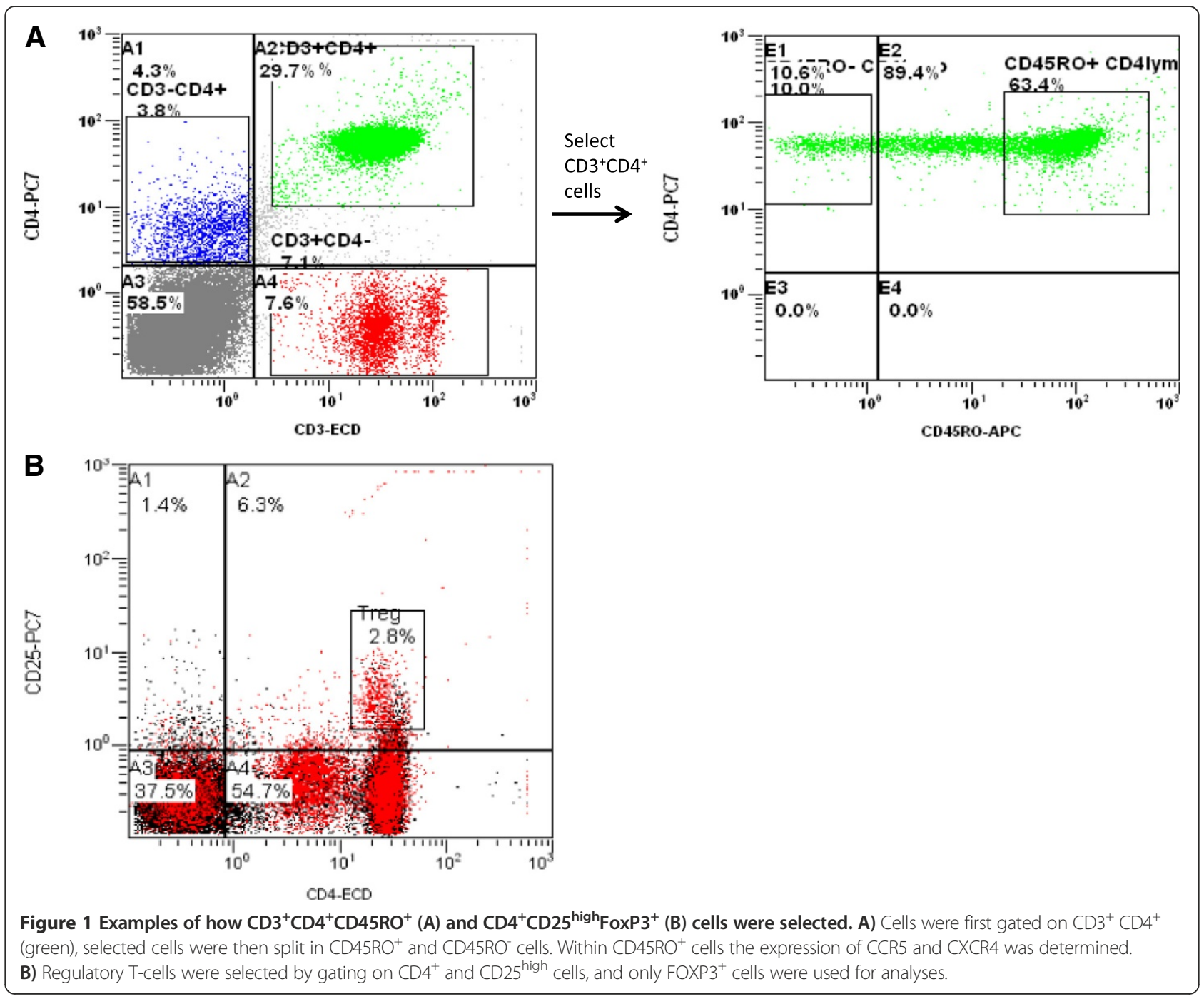

subsets the MFI of CCR5-expressing cells was lower in HIV-infected normal progressors compared to healthy controls (Figure 2C).

In LTNP, the proportion of $\mathrm{CD} 4^{+} \mathrm{T}$-cells that expressed CXCR4 was similar (Figure 3A). However, the MFI of CXCR4-expressing cells was significantly higher in

Table 1 Characteristics of ART-naïve HIV-infected individuals and controls devided per group $(n=25)$

\begin{tabular}{|c|c|c|c|}
\hline & \multicolumn{2}{|c|}{ HIV-infected } & \multirow[t]{2}{*}{ Healthy controls } \\
\hline & $\overline{L T N P}$ & $\begin{array}{l}\text { Normal } \\
\text { progressors }\end{array}$ & \\
\hline Number & 5 & 13 & 7 \\
\hline Median age, years & 49 & 39 & 41 \\
\hline Median CD4 cells, cells/ $\mu$ l & 1240 & 565 & n.a. \\
\hline Median Log (viral load) & 1.7 & 4.3 & n.a. \\
\hline
\end{tabular}

ART: antiretroviral therapy; HIV: human immunodeficiency virus; LTNP: long-term non-progressors; IQR: interquartile range.
HIV-infected normal progressors than healthy controls (Figure 3B). In all subsets of $\mathrm{CD}^{+}$T-lymphocytes the MFI of CXCR4-expressing cells was comparable between all groups. The differences between groups can be observed by two representative plots for all cell types for CCR5 (Figure 4) and CXCR4 (Figure 5).

The CCR $5 \triangle 32$ polymorphism in the CCR5 receptor may influence the expression of CCR5 [17]. Therefore we examined whether this polymorphism is more prevalent among the LTNP in this study. In total three people were heterozygote for the CCR5 $\triangle 32$ polymorphism (12\%), one of which was LTNP (1/5) and two were HIV-infected normal progressors $(2 / 12)$. No statistical difference was found between the prevalence of CCR $5 \Delta 32$ between LTNP and HIV-infected normal progressors $(\mathrm{p}=0.813)$. In addition, the CCR $5 \Delta 32$ polymorphism was not (significantly) associated with the percentage nor the MFI of CCR5-expressing and CXCR4-expressing cells. 
Table 2 Cell types and expression of CCR5 and CXCR4 for HIV-infected and uninfected individuals

\begin{tabular}{|c|c|c|c|c|}
\hline Cell type & Control & LTNP & HIV & p-value \\
\hline Total white blood cells, $\mathbf{n}\left(* \mathbf{1} \mathbf{0}^{6} / \mathbf{L}\right)$ & 6043 & 7060 & 5846 & 0.214 \\
\hline CD14+ of CD45+ cells & 9.0 & 8.2 & 10.1 & 0.186 \\
\hline CD3+ of CD45+ cells & 24.7 & 29.9 & 30.7 & 0.188 \\
\hline $\mathrm{CD} 8+\mathrm{CD} 3+$ of CD45 + cells & 7.2 & 11.5 & 19.1 & 0.003 \\
\hline CCR5+ & 50.6 & 43.1 & 57.8 & 0.161 \\
\hline CXCR4+ & 92.2 & 97.4 & 95.1 & 0.590 \\
\hline CD4 + CD3+ of CD45 + cells & 14.94 & 16.62 & 8.99 & 0.018 \\
\hline CCR5+ & 22.5 & 16.9 & 30.0 & 0.014 \\
\hline CXCR4+ & 70.2 & 83.7 & 71.9 & 0.185 \\
\hline CD45RO+ of CD3 + CD4+ cells & 49.6 & 45.6 & 52.6 & 0.360 \\
\hline CCR5+ & 40.1 & 30.5 & 44.4 & 0.065 \\
\hline CXCR4+ & 45.8 & 70.6 & 57.7 & 0.191 \\
\hline CD45RA+ of CD3 + CD4+ cells & 45.4 & 52.6 & 44.5 & 0.396 \\
\hline CCR5+ & 6.4 & 8.5 & 18.6 & 0.018 \\
\hline CXCR4+ & 91.6 & 94.6 & 90.3 & 0.595 \\
\hline $\mathrm{CD} 25^{\text {high }}$ FoxP3 + of CD3 + CD $4+$ cells & 6.5 & 4.8 & 5.4 & 0.091 \\
\hline CCR5+ & 49.1 & 41.9 & 49.4 & 0.790 \\
\hline CXCR4+ & 97.9 & 98.2 & 95.6 & 0.712 \\
\hline
\end{tabular}

Data are given as percentage unless stated otherwise.

Groups were compared with Kruskal-Wallis analyses.

HIV: human immunodeficiency virus; LTNP: long-term non-progressors; Control: HIV uninfected healthy controls.

\section{Discussion}

In this study we show that HIV infection is -directly or indirectly- associated with the expression of CCR5, but not CXCR4, in specific CD4 ${ }^{+}$T-lymphocyte subsets. This effect is most notable in HIV-infected normal progressors, but barely observed in LTNP with viral control.

CCR5 and CXCR4 are crucial for HIV invasion and they are expressed on various cell types, including hematopoietic cells and several cells in the central nervous system [7,12,17,22-27]. The expression of CCR5 can be affected by HIV and we show, in line with other studies, that HIV-infected individuals have an increased CCR5 expression on $\mathrm{CD}^{+}$T-lymphocytes [17,28-31]. Longitudinal studies show that the percentages of CCR5-expressing $\mathrm{CD}^{+}$cells increases slightly over time [17], while HAART reduces the percentage of CCR5-expressing cells $[28,29,31,32]$. This suggests, that indeed HIV increases the expression of CCR5 on CD4 ${ }^{+}$T-lymphocytes and that this effect is reversible. In contrast, we found no association between HIV and the surface density of CCR5, expressed by MFI. This also accords with earlier observations, which showed that surface density of CCR5 is stable over time $[18,33]$.

Recently, studies suggest that subtle genetic differences of HIV are associated with non-progression. HIV derived from long-term non-progressors has shown a reduced cell entry in vitro [1,34-37]. Also genetic differences in the host may play a role; the CCR $5 \Delta 32$ polymorphism is associated with lower numbers of CCR5-expressing $\mathrm{CD}_{4}{ }^{+}$T-cells [17] and slower progression of HIV [9,13-15]. However, the CCR5 $\Delta 32$ polymorphism is unrelated to the elevated expression of CCR5 in HIVinfected individuals, both in our study and that of others $[15,17,30]$. Despite these contradictory results, meta-analyses of published cohorts associate the CCR $5 \Delta 32$ with lower viral loads, decreased risk of progression to AIDS and lower mortality rate [13,38]. In addition slow progression could be associated with pathways including specific cellular proteins, such as restriction factors, APOBEC3, TRIM5, and Tetherin. These molecules act at several key steps of the HIV lifecycle and can avert viral infection or replication in a cell-specific way. As they control HIV infection, it is possible that genetic alterations or levels of expression are related to differences in HIV progression [39].

We demonstrate that in LTNP with viral control the expression of CCR5 is lower on both memory $\left(\mathrm{CD} 45 \mathrm{RO}^{+}\right)$ and naïve $\left(\mathrm{CD}^{2} 5 \mathrm{RA}^{+}\right) \mathrm{CD} 4+\mathrm{T}$-lymphocytes, but not on regulatory $\mathrm{T}$-cells $\left(\mathrm{CD} 4{ }^{+} \mathrm{CD} 25^{\text {high }} \mathrm{FoxP}^{+}\right)$. Only few studies examined co-receptors expression among specific HIV-infected patients, such as elite controls and LTNP, in combination with specific cell subsets $[24,40]$. Almeida et al. presents the CCR5 expression in dendritic cells of HIV-infected patients, including long term 


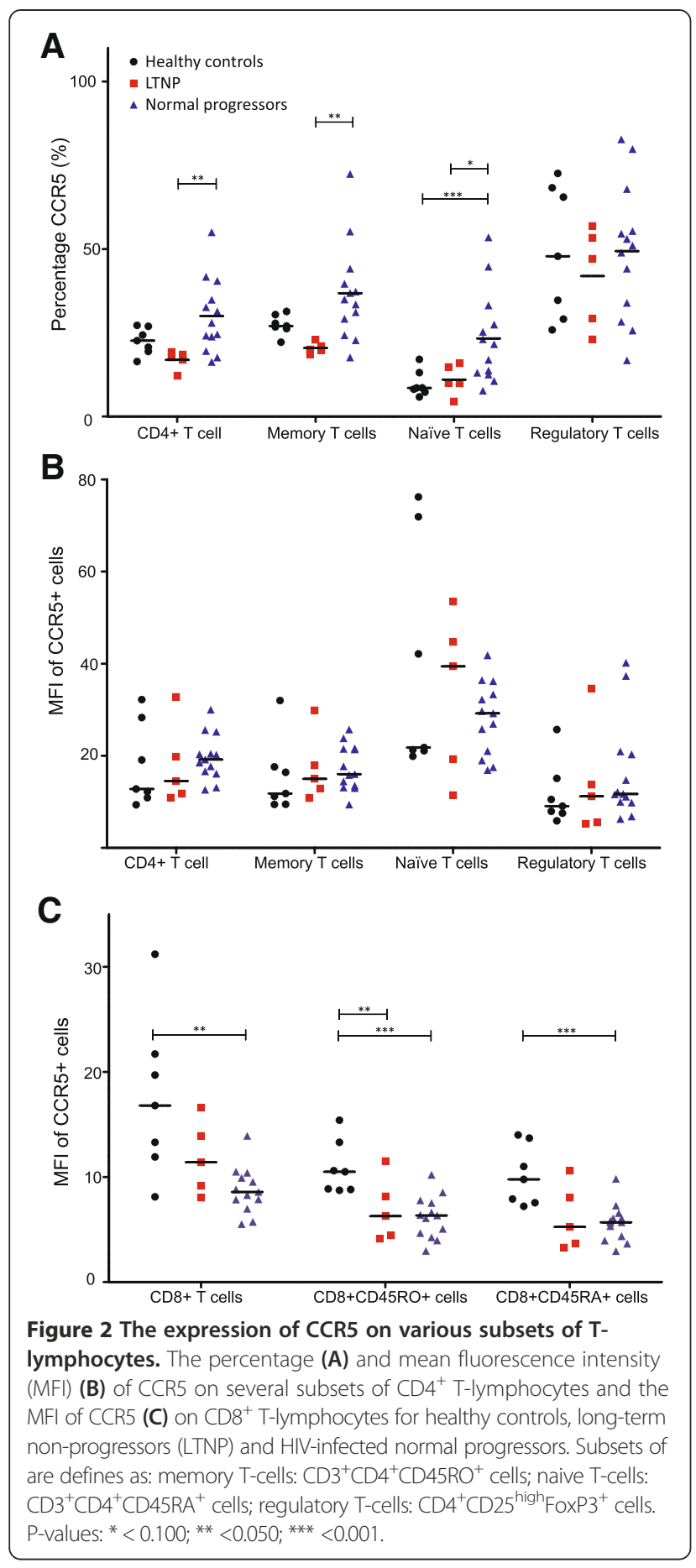

non-progressors. They found lower expression of CCR5 in all HIV-infected patients [40]. Other studies showed lower expression of CCR5 $\mathrm{CD}_{4}^{+} \mathrm{T}$ lymphocytes in HIV controllers [24,33]. Since CCR5 expression regulates whether HIV can infect target cells [41] and CCR5 down-regulation may contribute to the low levels of infection in LTNP.

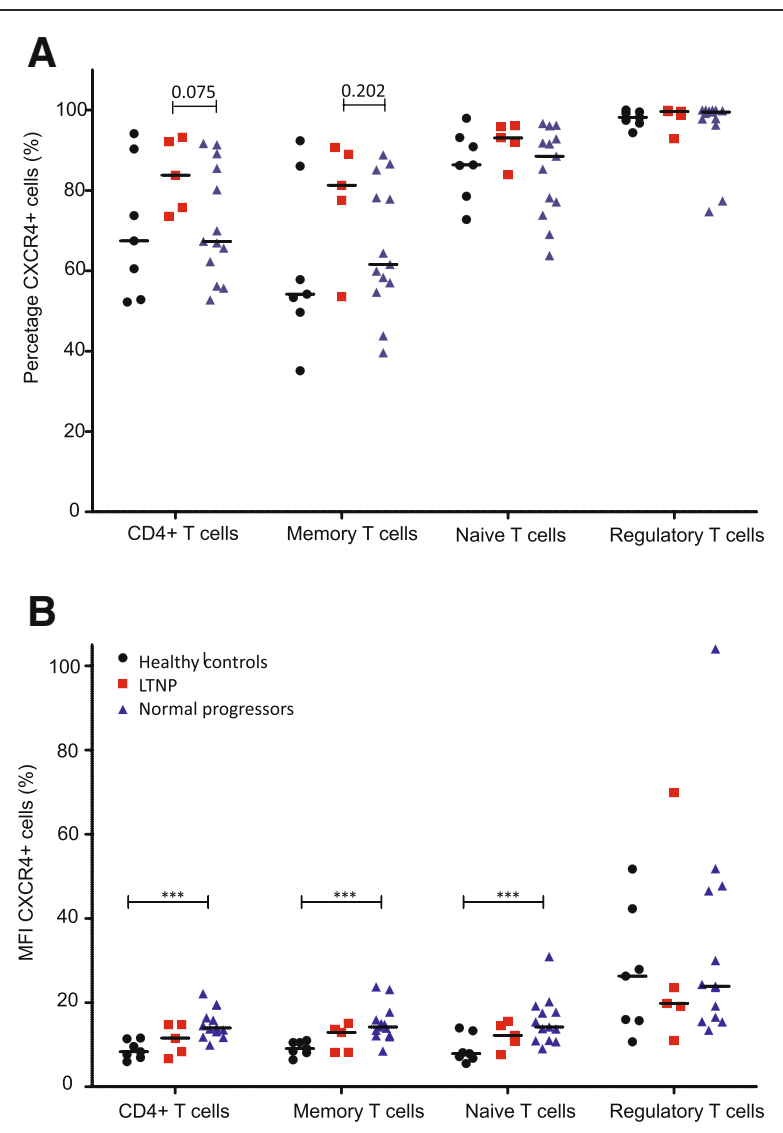

Figure 3 The expression of CXCR4 on various subsets of T-lymphocytes. The percentage (A) and mean fluorescence intensity (B) of CXCR4 on several subsets of CD4 ${ }^{+}$T-lymphocytes for healthy controls, long-term non-progressors (LTNP) and HIV-infected normal progressors. Subsets of are defines as: memory T-cells: $\mathrm{CD}^{+}$ $\mathrm{CD}^{+}{ }^{+} \mathrm{CD} 45 \mathrm{RO}^{+}$cells; naïve T-cells: $\mathrm{CD}^{+} \mathrm{CD}^{+} \mathrm{CD}^{+} 5 \mathrm{RA}^{+}$cells; regulatory T-cells: CD4 ${ }^{+}$CD25 ${ }^{\text {high }}$ FoxP3 ${ }^{+}$cells. P-values: ${ }^{*}<0.100 ;{ }^{* *}<0.050$; $* * * 00.001$.

Several studies analysed the association between the expression of CCR5 and disease progression, such as time to AIDS, CD4 cell decline or serum viral load levels. In both humans and animals, higher amounts of circulating $\mathrm{CD} 4^{+} \mathrm{CCR}^{+}{ }^{+}$T-lymphocytes are associated with faster disease progression, higher viral loads and lower CD4 cell counts $[17,18,30,33,42,43]$. Our findings further support an association between CCR5 expression and HIV progression. In addition, Yang et al. show that in mangabeys infected with SIV (simian immunodeficiency virus) the CCR5 expression is significantly lower on all subsets of cells in slow progressors compared to fast progressors; which supports our findings [43]. The downregulation of CCR5 in LTNP can be influenced by higher levels of chemokines, which activates receptor internalisation and thereby reduces CCR5 expression [12,44]. Also the amount of regulatory $\mathrm{T}$ cells are associated with disease progression; in line with other studies the amount of 


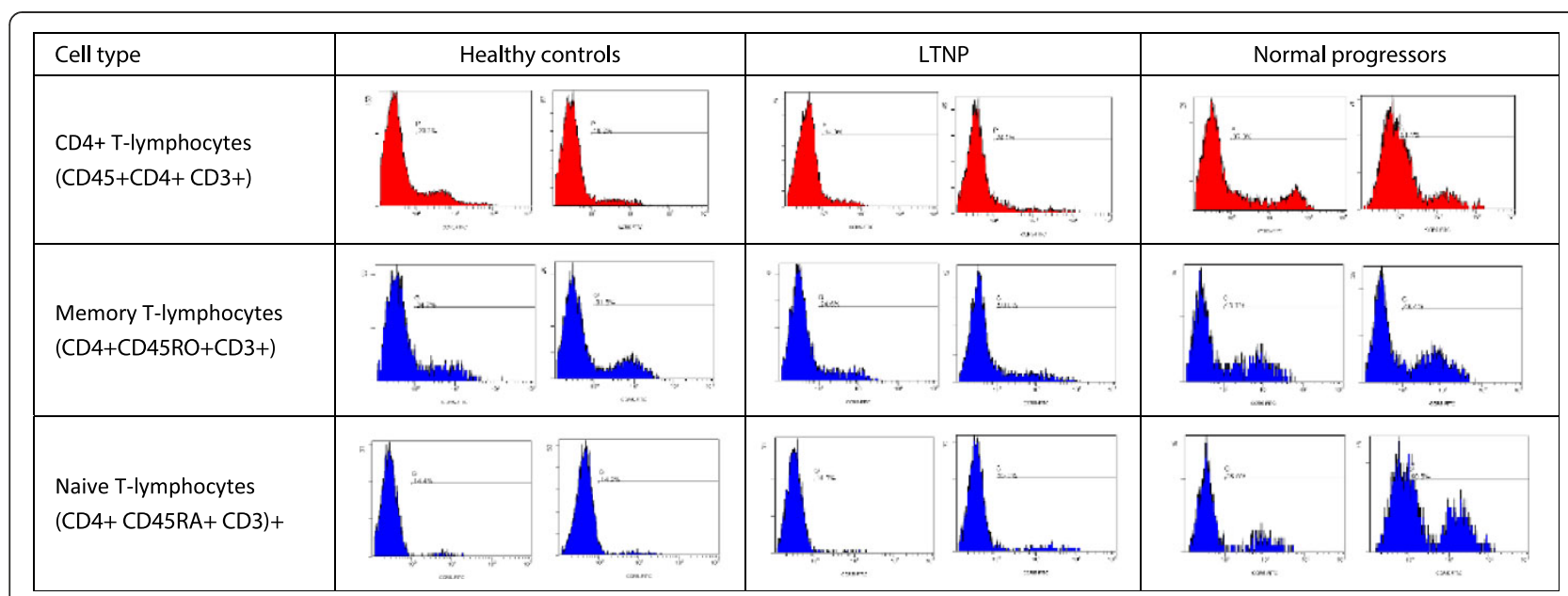

Figure 4 Representative plots of the expression of CCR5 on various cell types for different groups. Per group, namely healthy controls, long-term non-progressors (LTNP) and HIV-infected normal progressors, we show histograms from two representative subjects for the expression of CCR5.

regulatory T cells was higher in HIV normal progressors than in LRNP with viral control [13].

In our study, the amount of CXCR4-expressing cells was comparable between groups, but the MFI of CXCR4-expressing $\mathrm{CD} 4^{+}$T-lymphocytes was significantly increased in HIV-infected individuals. Literature on the expression of CXCR4 is inconclusive; some studies revealed no differences $[29,42]$, whereas others observed reduced CXCR4 expression on $\mathrm{CD}^{+}{ }^{+}$cells $[17,28,30,31]$, $\mathrm{CD}^{+}$cells $[28,30,31], \mathrm{CD}^{+} 4^{+}$cells [30] and natural killer cells [32]. CXCR4 is of more importance during later stages of infection [42] and therefore CXCR4 is probably less important in LTNP. In addition, all HIV-infected subjects in our study were asymptomatic and therefore the expression of CXCR4 might be affected by HIV at a later stage. Our study shows that LTNP with viral control tend to have a slightly higher number of CXCR4 expressing cells, albeit not significant, and also previous studies showed that there is a correlation between disease stage and CXCR4 expression of CD4 $4^{+} \mathrm{T}$-lymphocytes; with healthier patients expressing more CXCR4 [30].

\section{Conclusion}

In conclusion, the expression of CCR5 on $\mathrm{CD} 4^{+} \mathrm{T}-$ lymphocytes could be important in LTNP to counteract the effects of HIV and suppress viral replication. However,

\begin{tabular}{|l|c|c|c|}
\hline Cell type & Healthy controls \\
\hline $\begin{array}{l}\text { CD4+ T-lymphocytes } \\
\text { (CD45+CD4+CD3+) }\end{array}$ & \\
\hline $\begin{array}{l}\text { Memory T-lymphocytes } \\
\text { (CD4+CD45RO+CD3+) } \\
\text { (CD4+CD45RA+CD3) }\end{array}$ &
\end{tabular}

Figure 5 Representative plots of the expression of CXCR4 on various cell types for different groups. Per group, namely healthy controls, long-term non-progressors (LTNP) and HIV-infected normal progressors, we show histograms from two representative subjects for the expression of CXCR4. 
since this is a cross-sectional study the decreased expression of CCR5 could also be a consequence of the suppressed viral load in LTNP. Exploring whether LTNP suppress the upregulation of CCR5 could be an important step for discovering new therapeutics. Currently, CCR5 specific blockers, such as Maraviroc, are already used effectively in HIV treatment regimes, showing the importance of CCR5 in HIV suppression.

\section{Competing interests}

All authors declare that they have no competing interests.

\section{Authors' contributions}

All authors have significantly contributed to this study and have seen and approved the last version of the manuscript. No writing assistance was provided in the preparation of this manuscript. HM participated in the design of the study, carried out the experiments, performed statistical analyses and drafted the manuscript. Al assisted in the FACS analyses and statistical analyses. RvC participated in the design of the study and drafting the manuscript. IJ and HK assisted in statistical analyses, interpretation of the data and drafting the manuscript. AvV participated in the design of the study, coordination and helped to draft the manuscript. All other authors have read and approved the final manuscript.

\section{Acknowledgements}

We want to thank Marjolein Bosch, Rolina Meijering and Anne-Marie Goedhart-Camp for informing and recruiting the participants of this study Cor Jacobs, Esther Fasse and Esther van Rijssen are thanked for their help and support with the FACS analyses. In addition, we would like to thank all participants for taking part in this study. RvC. was supported by a Vidi Grant from the Netherlands Organization for Scientific Research.

\section{Author details}

'Department of Internal Medicine, Radboud University Medical Center, Route 456, PO Box 910, 6500 HB, Nijmegen, The Netherlands. ${ }^{2}$ Health Research Unit, Faculty of Medicine, Universitas Padjadjaran/Hasan Sadikin Hospital, Bandung, Indonesia. ${ }^{3}$ Laboratory of Medical Immunology, Department of Laboratory Medicine, Radboud University Medical Center, Nijmegen, The Netherlands.

Received: 11 June 2014 Accepted: 4 December 2014

Published online: 13 December 2014

\section{References}

1. Zaunders J, van Bockel D: Innate and adaptive immunity in long-term Non-progression in HIV disease. Front Immunol 2013, 4:95

2. McCune JM: The dynamics of CD4+ T-cell depletion in HIV disease. Nature 2001, 410(6831):974-979.

3. Andersson J, Boasso A, Nilsson J, Zhang R, Shire NJ, Lindback S, Shearer GM, Chougnet CA: The prevalence of regulatory T cells in lymphoid tissue is correlated with viral load in HIV-infected patients. J Immunol 2005, 174(6):3143-3147.

4. Kabat D, Kozak SL, Wehrly K, Chesebro B: Differences in CD4 dependence for infectivity of laboratory-adapted and primary patient isolates of human immunodeficiency virus type 1. J Virol 1994, 68(4):2570-2577.

5. Schuitemaker H, Kootstra NA, de Goede RE, de Wolf F, Miedema F, Tersmette M: Monocytotropic human immunodeficiency virus type 1 (HIV-1) variants detectable in all stages of HIV-1 infection lack T-cell line tropism and syncytium-inducing ability in primary T-cell culture. J Virol 1991, 65(1):356-363.

6. Brumme ZL, Goodrich J, Mayer HB, Brumme CJ, Henrick BM, Wynhoven B, Asselin JJ, Cheung PK, Hogg RS, Montaner JS, Harrigan PR: Molecular and clinical epidemiology of CXCR4-using HIV-1 in a large population of antiretroviral-naive individuals. J Infect Dis 2005, 192(3):466-474.

7. Bleul CC, Wu L, Hoxie JA, Springer TA, Mackay CR: The HIV coreceptors CXCR4 and CCR5 are differentially expressed and regulated on human T lymphocytes. Proc Natl Acad Sci U S A 1997, 94(5):1925-1930.

8. Loetscher P, Moser B, Baggiolini M: Chemokines and their receptors in lymphocyte traffic and HIV infection. Adv Immunol 2000, 74:127-180.
9. Dean M, Carrington M, Winkler C, Huttley GA, Smith MW, Allikmets R, Goedert JJ, Buchbinder SP, Vittinghoff E, Gomperts E, Donfield S, Vlahov D, Kaslow R, Saah A, Rinaldo C, Detels R, O'Brien SJ: Genetic restriction of HIV-1 infection and progression to AIDS by a deletion allele of the CKR5 structural gene. Hemophilia growth and development study, multicenter AIDS cohort study, multicenter hemophilia cohort study, San Francisco city cohort, ALIVE study. Science 1996, 273(5283):1856-1862.

10. Poropatich $K$, Sullivan DJ Jr: Human immunodeficiency virus type 1 long-term non-progressors: the viral, genetic and immunological basis for disease non-progression. J Gen Virol 2011, 92(Pt 2):247-268.

11. Eugen-Olsen J, Iversen AK, Garred P, Koppelhus U, Pedersen C, Benfield TL, Sorensen AM, Katzenstein T, Dickmeiss E, Gerstoft J, Skinhoj P, Svejgaard A, Nielsen JO, Hofmann B: Heterozygosity for a deletion in the CKR-5 gene leads to prolonged AIDS-free survival and slower CD4 T-cell decline in a cohort of HIV-seropositive individuals. AIDS 1997, 11(3):305-310.

12. Arenzana-Seisdedos F, Parmentier M: Genetics of resistance to HIV infection: Role of co-receptors and co-receptor ligands. Semin Immunol 2006, 18(6):387-403.

13. loannidis JP, Rosenberg PS, Goedert JJ, Ashton LJ, Benfield TL, Buchbinder SP, Coutinho RA, Eugen-Olsen J, Gallart T, Katzenstein TL, Kostrikis LG, Kuipers H, Louie LG, Mallal SA, Margolick JB, Martinez OP, Meyer L, Michael NL, Operskalski E, Pantaleo G, Rizzardi GP, Schuitemaker H, Sheppard HW, Stewart GJ, Theodorou ID, Ullum H, Vicenzi E, Vlahov D, Wilkinson D, Workman C: Effects of CCR5-Delta, 32, CCR2-64I, and SDF-1 3'A alleles on HIV-1 disease progression: An international meta-analysis of individual-patient data. Ann Intern Med 2001, 135(9):782-795.

14. Morawetz RA, Rizzardi GP, Glauser D, Rutschmann O, Hirschel B, Perrin L, Opravil M, Flepp M, von Overbeck J, Glauser MP, Ghezzi S, Vicenzi E, Poli G, Lazzarin A, Pantaleo G: Genetic polymorphism of CCR5 gene and HIV disease: the heterozygous (CCR5/delta ccr5) genotype is neither essential nor sufficient for protection against disease progression. Swiss HIV Cohort. Eur J Immunol 1997, 27(12):3223-3227.

15. Cohen OJ, Paolucci S, Bende SM, Daucher M, Moriuchi H, Moriuchi M, Cicala C, Davey RT Jr, Baird B, Fauci AS: CXCR4 and CCR5 genetic polymorphisms in long-term nonprogressive human immunodeficiency virus infection: lack of association with mutations other than CCR5-Delta32. J Virol 1998, 72(7):6215-6217.

16. Platt EJ, Wehrly K, Kuhmann SE, Chesebro B, Kabat D: Effects of CCR5 and CD4 cell surface concentrations on infections by macrophagetropic isolates of human immunodeficiency virus type 1. J Virol 1998, 72(4):2855-2864.

17. de Roda Husman AM, Blaak H, Brouwer M, Schuitemaker H: CC chemokine receptor 5 cell-surface expression in relation to CC chemokine receptor 5 genotype and the clinical course of HIV-1 infection. J Immunol 1999, 163(8):4597-4603.

18. Reynes J, Portales P, Segondy M, Baillat V, Andre P, Reant B, Avinens O, Couderc G, Benkirane M, Clot J, Eliaou JF, Corbeau P: CD4+ T cell surface CCR5 density as a determining factor of virus load in persons infected with human immunodeficiency virus type 1. J Infect Dis 2000, 181(3):927-932.

19. Giovannetti A, Pierdominici M, Mazzetta F, Salemi S, Marziali M, Kuonen D, lebba F, Lusi EA, Cossarizza A, Aiuti F: T cell responses to highly active antiretroviral therapy defined by chemokine receptors expression, cytokine production, $\mathrm{T}$ cell receptor repertoire and anti-HIV T-lymphocyte activity. Clin Exp Immunol 2001, 124(1):21-31.

20. Piacentini L, Biasin M, Fenizia C, Clerici M: Genetic correlates of protection against HIV infection: the ally within. J Intern Med 2009, 265(1):110-124.

21. Martinson JJ, Chapman NH, Rees DC, Liu YT, Clegg JB: Global distribution of the CCR5 gene 32-basepair deletion. Nat Genet 1997, 16(1):100-103.

22. Kim $\mathrm{CH}$, Broxmeyer $\mathrm{HE}$ : Chemokines: signal lamps for trafficking of $\mathrm{T}$ and $\mathrm{B}$ cells for development and effector function. J Leukoc Biol 1999, 65(1):6-15.

23. Syrbe U, Siveke J, Hamann A: Th1/Th2 subsets: distinct differences in homing and chemokine receptor expression? Springer Semin Immunopathol 1999, 21(3):263-285.

24. Potter SJ, Lacabaratz C, Lambotte $O$, Perez-Patrigeon S, Vingert B, Sinet M, Colle JH, Urrutia A, Scott-Algara D, Boufassa F, Delfraissy JF, Theze J, Venet A, Chakrabarti LA: Preserved central memory and activated effector memory CD4+ T-cell subsets in human immunodeficiency virus controllers: an ANRS EP36 study. J Virol 2007, 81(24):13904-13915.

25. Corbeau P, Reynes J: CCR5 antagonism in HIV infection: ways, effects, and side effects. AIDS 2009, 23(15):1931-1943. 
26. Bonecchi R, Bianchi G, Bordignon PP, D'Ambrosio D, Lang R, Borsatti A, Sozzani S, Allavena P, Gray PA, Mantovani A, Sinigaglia F: Differential expression of chemokine receptors and chemotactic responsiveness of type 1 T helper cells (Th1s) and Th2s. J Exp Med 1998, 187(1):129-134.

27. Gorry PR, Ancuta P: Coreceptors and HIV-1 pathogenesis. Curr HIV/AIDS Rep 2011, 8(1):45-53.

28. Giovannetti A, Ensoli F, Mazzetta F, De Cristofaro M, Pierdominici M, Muratori DS, Fiorelli V, Aiuti F: CCR5 and CXCR4 chemokine receptor expression and beta-chemokine production during early $\mathrm{T}$ cell repopulation induced by highly active anti-retroviral therapy. Clin Exp Immunol 1999, 118(1):87-94.

29. Nicholson JK, Browning SW, Hengel RL, Lew E, Gallagher LE, Rimland D, McDougal JS: CCR5 and CXCR4 expression on memory and naive T cells in HIV-1 infection and response to highly active antiretroviral therapy. J Acquir Immune Defic Syndr 2001, 27(2):105-115.

30. Ostrowski MA, Justement SJ, Catanzaro A, Hallahan CA, Ehler LA, Mizell SB, Kumar PN, Mican JA, Chun TW, Fauci AS: Expression of chemokine receptors CXCR4 and CCR5 in HIV-1-infected and uninfected individuals. J Immunol 1998, 161(6):3195-3201.

31. Pierdominici M, Giovannetti A, Ensoli F, Mazzetta F, Marziali M, De Cristofaro MR, Santini-Muratori D, Leti W, Aiuti F: Changes in CCR5 and CXCR4 expression and beta-chemokine production in HIV-1-infected patients treated with highly active antiretroviral therapy. J Acquir Immune Defic Syndr 2002, 29(2):122-131.

32. Jiang Y, Zhang Z, Diao Y, Jin X, Shi W, Geng W, Dai D, Zhang M, Han X, Liu J, Wang $Y$, Shang H: Expression of chemokine receptors on natural killer cells in HIV-infected individuals. Cell Immunol 2008, 251(1):19-24.

33. Reynes J, Portales P, Segondy M, Baillat V, Andre P, Avinens O, Picot MC, Clot J, Eliaou JF, Corbeau P: CD4 T cell surface CCR5 density as a host factor in HIV-1 disease progression. AIDS 2001, 15(13):1627-1634.

34. Mwimanzi P, Markle TJ, Martin E, Ogata Y, Kuang XT, Tokunaga M, Mahiti M, Pereyra F, Miura T, Walker BD, Brumme ZL, Brockman MA, Ueno T: Attenuation of multiple Nef functions in HIV-1 elite controllers. Retrovirology 2013, 10:1.

35. Alexander L, Weiskopf E, Greenough TC, Gaddis NC, Auerbach MR, Malim MH, O'Brien SJ, Walker BD, Sullivan JL, Desrosiers RC: Unusual polymorphisms in human immunodeficiency virus type 1 associated with nonprogressive infection. J Virol 2000, 74(9):4361-4376.

36. Miura T, Brockman MA, Brumme CJ, Brumme ZL, Carlson JM, Pereyra F, Trocha A, Addo MM, Block BL, Rothchild AC, Baker BM, Flynn T, Schneidewind A, Li B, Wang YE, Heckerman D, Allen TM, Walker BD: Genetic characterization of human immunodeficiency virus type 1 in elite controllers: lack of gross genetic defects or common amino acid changes. J Virol 2008, 82(17):8422-8430.

37. Lassen KG, Lobritz MA, Bailey JR, Johnston S, Nguyen S, Lee B, Chou T, Siliciano RF, Markowitz M, Arts EJ: Elite suppressor-derived HIV-1 envelope glycoproteins exhibit reduced entry efficiency and kinetics. PLoS Pathog 2009, 5(4):e1000377.

38. Santa-Marta M, de Brito PM, Godinho-Santos A, Goncalves J: Host Factors and HIV-1 Replication: Clinical Evidence and Potential Therapeutic Approaches. Front Immunol 2013, 4:343.

39. Borinskaya SA, Kozhekbaeva Zh M, Zalesov AV, Olseeva EV, Maksimov AR, Kutsev SI, Garaev MM, Rubanovich AV, Yankovsky NK: Risk of HIV infection and lethality Are decreased in CCR5del32 heterozygotes: focus nosocomial infection study and meta-analysis. Acta Nat 2012, 4(1):42-52.

40. Almeida M, Cordero M, Almeida J, Orfao A: Different subsets of periphera blood dendritic cells show distinct phenotypic and functional abnormalities in HIV-1 infection. AIDS 2005, 19(3):261-271.

41. Blaak H, Ran L, Rientsma R, Schuitemaker H: Susceptibility of in vitro stimulated PBMC to infection with NSI HIV-1 is associated with levels of CCR5 expression and beta-chemokine production. Virology 2000, 267(2):237-246.

42. Monceaux V, Viollet L, Petit F, Cumont MC, Kaufmann GR, Aubertin AM, Hurtrel B, Silvestri G, Estaquier J: CD4+ CCR5+ T-cell dynamics during simian immunodeficiency virus infection of Chinese rhesus macaques. J Virol 2007, 81(24):13865-13875.
43. Yang $X$, Jiao $Y M$, Wang $R$, Ji YX, Zhang HW, Zhang $Y H$, Chen DX, Zhang $T$, Wu H: High CCR5 density on central memory CD4+ T cells in acute HIV-1 infection is mostly associated with rapid disease progression. PLOS One 2012, 7(11):e49526.

44. Neel NF, Schutyser E, Sai J, Fan GH, Richmond A: Chemokine receptor internalization and intracellular trafficking. Cytokine Growth Factor Rev 2005, 16(6):637-658.

doi:10.1186/s12879-014-0683-0

Cite this article as: Meijerink et al:: The number of CCR5 expressing CD4+ T lymphocytes is lower in HIV-infected long-term non-progressors with viral control compared to normal progressors: a cross-sectional study. BMC Infectious Diseases 2014 14:683.

\section{Submit your next manuscript to BioMed Central and take full advantage of:}

- Convenient online submission

- Thorough peer review

- No space constraints or color figure charges

- Immediate publication on acceptance

- Inclusion in PubMed, CAS, Scopus and Google Scholar

- Research which is freely available for redistribution

Submit your manuscript at www.biomedcentral.com/submit
() BioMed Central 